\title{
A Case of Chronic Hepatitis B Virus Infection in an Anti-HBc- negative Patient: An Atypical Serological Profile
}

\author{
Atipik Serolojik Profil Olarak Anti-HBc Negatif Kronik Hepatit B Virüs Enfeksiyonu Olgusu
}

\author{
Murat AFYON1', Berksan ŞIMŞEK², Ayper KAYA³ \\ ${ }^{1}$ Gülhane Military Medical Academy Haydarpaşa Training Hospital, First Step Examination and Family Health Center and Naval Academy Clinic, Istanbul, Turkey \\ 2Kasımpaşa Military Hospital, Clinic of Microbiology, Istanbul, Turkey \\ ${ }^{3}$ Kasımpaşa Military Hospital, Clinic of Pathology, Istanbul, Turkey
}

\begin{abstract}
Antibodies against hepatitis B virus (HBV) core antigen (anti$\mathrm{HBC}$ ) are assumed to be the best serologically reliable markers of HBV infection. However, chronic HBV infection can be seen with an atypical serological profile, such as anti-HBc negativity with the presence of hepatitis B surface antigen (HBsAg). Anti-HBc negativity during HBV infection has been observed in a few different circumstances, such as infections with HBV variants, in infants born to hepatitis $B$ envelope antigen positive carrier mothers and immunocompromised patients. In this case, we described a 21-yearold anti-HBc-negative male patient with chronic HBV infection.
\end{abstract}

Keywords: Anti-HBc, hepatitis B virus, atypical serology

\section{$\ddot{O Z Z}$}

Hepatit B virüs (HBV) core antijenine ( $\mathrm{HBcAg}$ ) karşı antikorlar (anti$\mathrm{HBC}), \mathrm{HBV}$ enfeksiyonu için güvenilir serolojik belirteçlerden biridir. Ancak HBV enfeksiyonu bazen hepatit B yüzey antijeni (HBsAg) varlığına rağmen anti-HBc negatifliğinin görüldüğü atipik bir serolojik profil ile ilişkili olabilir. HBV enfeksiyonu süresince anti-HBc üretiminde defekt, HBV varyantları ile enfeksiyon, hepatit B envelope antigeni pozitif anneden doğan infantlar ve immünsüpresif hastalar gibi birkaç durumda gözlenmiştir. Bu olgumuzda, 21 yaşında bir erkek hastada anti-HBc negatif kronik HBV enfeksiyonu tariflenmektedir.

Anahtar Kelimeler: Anti-HBc, hepatit B virüsü, atipik seroloji

\section{Introduction}

The diagnosis of hepatitis $B$ virus (HBV) infection is established by the serological detection of HBV antigens and host produced antibodies against them. If HBV surface antigen (HBsAg) persists for more than six months, the infected individual is considered to be a chronic HBV carrier (1).

HBV core antigen $(\mathrm{HBcAg})$, not a secreted protein, exists primarily in the liver and in serum within HBV particles, not being in the blood directly accessible to the immune system. Antibodies to $\mathrm{HBcAg}$ (anti-HBc) are considered to be the best serologically reliable markers of HBV infection. Not only chronic HBV carriers, but also healthy individuals, who have natural immunity to HBV due to past infection, are positive for anti-HBc. Therefore, anti-HBc is the most important marker indicating past HBV infection as well as ongoing infection (2).

Anti-HBc levels can show significant differences during the natural course of chronic HBV infection and, isolated HBsAg positivity without anti-HBc can be seen in acute infection $(1,3)$. However, during chronic HBV infection, the absence of anti-HBC with the persistent positivity for HBsAg and detectable HBV DNA comprises an atypical serological profile $(1,3)$.

\section{Case}

A 21-year-old male patient was positive for HBsAg. HBsAg positivity was identified approximately one year ago. He had no history of liver biopsy or treatment for HBV infection when he was referred to our outpatient clinic. He had no active complaint. There was not any remarkable feature (e.g., chronic disease, immunosuppressive status or continuous drug use) on admission. The patient's mother and sister had a history of HBV infection. No pathological finding was detected during physical examination.

Laboratory examination showed that serum glucose, urea, creatinine, lipids, electrolytes, bilirubins, alkaline phosphatase, gammaglutamyl transaminase and blood cell count were all within 
the normal limits. Aspartate aminotransferase (AST) was $26 \mathrm{U} / \mathrm{l}$, alanine aminotransferase (ALT) was $58 \mathrm{U} / \mathrm{l}$.

As a result of serological assays, $\mathrm{HBsAg}$ and hepatitis $\mathrm{B}$ envelope antigen ( $\mathrm{HBeAg}$ ) were positive; anti-HBc total, anti-HBs, anti-HBe, anti-HBc lgM, anti-HAV lgG, anti-HCV, and anti-HIV were negative. Since he was positive for $\mathrm{HBsAg}$ but negative for anti-HBc total, we repeated the serology tests and the same results were obtained. The results of the repeated tests with Abbott Axsym Core $^{\mathrm{TM}}$ were negative for anti-HBc. Then, anti-HBc negativity was also obtained by Abbott Architect Anti-HBc II.

HBV DNA level was high (2.050.201.984 IU/mL) by Taqman Real Time polymerase chain reaction assay, Fluorion HBV QNP 2.0 (Istanbul, Turkey). Abdominal ultrasound results were normal. Liver biopsy results indicated chronic hepatitis B with a mild necroinflammatory activity and mild fibrosis (Knodell's score: Grade; 3/18, stage; 2/6).

\section{Discussion}

The rate of chronic HBV infection with antiHBc negativity ranged from $0.05 \%$ to $1.79 \%$ in different studies $(1,3,4)$. Anti-HBc negativity during HBV infection has been observed in a few different circumstances, such as false negativity, sample contamination, HBV variants with especially deletions in the core gene, immune tolerance to $\mathrm{HBcAg}$, infants born to HBeAg-positive carrier mothers, immunocompromised patients or patients with circulating immune complexes composed of anti-HBc and HBcAg $(1,3)$.

The diagnostic tests have continuously improved over the last few decades. Sensitivity and specificity differences exist between assays and may sometimes explain the discrepant results in some patients. Positive results detected by repeated tests with different kits in anti-HBc-negative individuals have been reported $(3,4,5,6)$. In our patient, the results of repeated tests with Abbott Axsym CoreTM were negative. Then, anti-HBc negativity was also obtained by Abbott Architect Anti-HBc II. While different data have been reported for specificity of Abbott anti-HBc assays, high values for sensitivity (99.1\%, 98\%) and negative predictive value (99.6\%) have been reported for Abbott Architect Anti-HBc II and it has been assessed as reliable $(3,5,6,7)$. In addition,, nonspecificity problem observed in old Abbott anti-HBc assays, including Abbott Axsym CoreTM, has been reported to be solved with Abbott Architect Anti-HBc II $(3,7)$.

The immune tolerance to $\mathrm{HBcAg}$ is known by the incapacity of the individual to produce anti-HBc or to produce it in undetectable levels (1). The immune tolerance can be caused by T-cell anergy, a small number of specific peripheral T lymphocytes, an inefficient antigen presentation or an inefficient lymphokine production by the antigen-presenting cell (1). Therefore, a selective immune system defect could lead the immune tolerance to HBcAg and, consequently, lack of production of anti-HBc and existence of this atypical serological profile $(1,3)$. In anti-HBc-negative patients with chronic HBV infection, a relative immunosupression due to coinfection with human immunodeficiency virus (HIV), history of transplantation (kidney, heart or bone marrow), history of chemotherapy, leukemia, end-stage renal failure and systemic inflammatory diseases, such as histiocytosis $x$ and sarcoidosis, have been reported $(1,3,8)$. It is emphasized that the absence of anti-HBc was concomitant with a more severe immunosuppression like a CD4-cell count of less than $50 / \mathrm{mm}^{3}$ and HIV plasma volume above 100.000 copies per $\mathrm{ml}$, while anti-HBc was detectable when the level of immunosuppression was less significant (3). In our patient, he was negative for anti-HIV and there was no immunosuppressive status which could lead to anti-HBc negativity induced by reduction of antibody production.

Lack of anti-HBc production also has been reported in infants born to HBeAg-positive carrier mothers due to helper T-cell tolerance to $\mathrm{HBcAg}$ and $\mathrm{HBeAg}$ induced by transplacental maternal $\mathrm{HBeAg}(1,3,9)$. The mother and sister of our patient had a history of HBV infection and since immunoprophylaxis was not routine in our country during the period our patient was born, it can be considered that the risk of perinatal transmission was higher.

HBV variants with core mutations could cause infections with a low level of production or a lack of detection of anti-HBc $(1,10)$. Variant core HBV strains are expected to be defective for B-cell epitopes and T-helper cell epitopes, which are mainly between 80 and 140 amino acids of the core protein. This may explain the low level production of anti-HBc which was detectable only with a very sensitive assay as demonstrated in mice experiments (10). Although the absence of anti-HBc has also been attributed to a new virus termed HBV2, discrepant data have been produced since this first report without further characterization of this virus $(3,4,11)$. At the same time, there are studies that have not detected any mutation which could lead to anti-HBc negativity $(3,4,8,9)$. In our patient, HBV DNA sequence analysis was not performed.

There is an opinion that the presence or absence of $\mathrm{HBeAg}$ in this atypical serological profile may be associated with the mechanism that justifies the profile (1). For example, in the case of immune tolerance to $\mathrm{HBcAg}$ or vertical transmission, the presence of $\mathrm{HBeAg}$ in the profile seems likely, since precore/core regions remain unchanged and normal synthesis of viral antigen goes on. On the other hand, following the occurrence of core gene deletions, depending on the region involved, the absence of $\mathrm{HBeAg}$ may occur, since both antigens are encoded by the same gene (1). Our patient was positive for HBeAg.

$\mathrm{HBcAg}$ can be secreted rarely from infected hepatocytes after liver necrosis during the phase of active replication of infection in a state of immunosuppression, such as coinfection with HIV, transplantation and chemotherapy $(1,8)$. Immune complex formation of anti-HBc with $\mathrm{HBcAg}$ can occur because of the excessive presence of HBcAg in the bloodstream and, thus, anti-HBc can become undetectable. Our patient had mild necroinflammatory activity, he was negative for anti-HIV, and there was no immunosuppressive status which could lead to anti-HBc negativity induced by immune complexes occurrence.

Considering our patient and the available data in the literature, although there is an important shortcoming like not performed HBV DNA sequence analysis, since there was no serious immunosuppressive status, which could lead to anti-HBc negativity induced by immune complexes occurrence or by reduction of antibody production, his mother and sister had a history of $\mathrm{HBV}$ infection, there was high risk of perinatal transmission in our country during the period the patient was born and he was negative for anti-HIV and positive for $\mathrm{HBeAg}$, and he had mild necroinflammatory activity, we thought that immune tolerance by perinatal transmission could be probable cause of chronic HBV infection in our anti-HBc-negative patient, 
A minimal ALT elevation, mild fibrosis and mild necroinflammatory activity was detected in our patient. The relationship between anti-HBc negativity and liver damage remains unclear. There are studies showing increased liver damage in anti-HBc-negative patients with chronic HBV infection, or no relationship between them $(3,10)$.

\section{Conclusion}

As a conclusion, anti-HBc levels can show significant differences during the natural course of chronic HBV infection and isolated HBsAg positivity without anti-HBc can be seen in acute infection. However, during chronic HBV infection, an atypical serological profile characterized by the presence of HBsAg without anti-HBc can be seen in infections with HBV variants, in infants born to $\mathrm{HBeAg}$ positive carrier mothers and immunocompromised patients. The effect of anti-HBc negativity on prognosis remains unclear.

\section{Ethics}

Peer-review: External and Internal peer-reviewed.

\section{Authorship Contributions}

Surgical and Medical Practices: Murat Afyon, Berksan Şimşek, Ayper Kaya, Concept: Murat Afyon, Design: Murat Afyon, Data Collection or Processing: Murat Afyon, Berksan Şimşek, Ayper Kaya, Analysis or Interpretation: Murat Afyon, Berksan Şimşek, Ayper Kaya, Literature Search: Murat Afyon, Berksan Şimşek, Ayper Kaya, Writing: Murat Afyon.

Conflict of Interest: No conflict of interest was declared by the authors.

Financial Disclosure: The authors declared that this study has received no financial support.

Afyon M, Simșek B, Kaya A. A Case of Chronic Hepatitis B Virus Infection in an Anti-HBc Negative Patient: An Atypical Serological Profile. Viral Hepatitis J 2016;22:34-36.

\section{References}

1. Pondé RA. Atypical serological profiles in hepatitis $B$ virus infection. Eur J Clin Microbiol Infect Dis. 2013;32:461-476.
2. Jia W, Song $L W$, Fang $Y Q$, Wu XF, Liu DY, Xu C, Wang XM, Wang W, Lv DX, Li J, Deng YQ, Wang Y, Huo N, Yu M,Xi HL, Liu D, Zhou YX, Wang GQ, Xia NS, Zhang MX. Antibody to hepatitis $B$ core antigen levels in the natural history of chronic hepatitis B: a prospective observational study. Medicine (Baltimore). 2014;93:322.

3. Avettand-Fenoel V, Thabut D, Katlama C, Poynard T, Thibault $V$. Immune suppression as the etiology of failure to detect anti-HBc antibodies in patients with chronic hepatitis $B$ virus infection. J Clin Microbiol. 2006;44:2250-2253.

4. Laperche S, Guitton C, Smilovici W, Courouce AM. Blood donors infected with the hepatitis B virus but persistently lacking antibodies to the hepatitis B core antigen. Vox Sang. 2001;80:90-94.

5. Seiskari T, Lehtisaari H, Haapala AM, Aittoniemi J. From Abbott ARCHITECT anti-HBc to Anti-HBc Il--improved performance in detecting antibodies to hepatitis B core antigen. J Clin Virol. 2010;47:100-101.

6. Kobayashi E, Deguchi M, Kagita M, Yoshioka N, Kita M, Asari S, Suehisa E, Hidaka Y, Iwatani Y. Performance evaluation of four dominant anti-hepatitis B core antigen (HBcAb) kits in Japan for preventing de novo hepatitis B virus (HBV) infection. Clin Lab. 2015;61:77-85.

7. Ba Alawi F, Robertson PW, LePage AK, Jayamaha J, Baleriola C, Rawlinson WD. The reliability of HBV core antibody in serological screening for hepatitis B virus. Pathology. 2013;45:501-505.

8. Melegari $M$, Jung $M C$, Schneider R,Santantonio T, Bagnulo $S$, Luchena N,Pastore G, Pape G, Scaglioni PP, Villa E. Conserved core protein sequences in hepatitis $B$ virus infected patients without anti-HBc. J Hepatol. 1991;13:187-191.

9. Ni YH, Hsu HY, Chang MH, Chen DS, Lee CY. Absence or delayed appearance of hepatitis B core antibody in chronic hepatitis B surface antigen carrier children. J Hepatology. 1993;17:150-154.

10. Zoulim F, Zhang X, Pichoud C, Trepo C. Heterogeneity of hepatitis $B$ virus (HBV) core gene in a patient with HBVassociated cirrhosis and serum negativity for anti-HBc. J Hepatol. 1996;24:155-160.

11. Coursaget $P, Y$ vonne B, Bourdil C, Buisson $Y$, Chotard J, N'Doye R, Molinie C, Diop-Mar I, Chiron JP. Hepatitis B surface antigen reactivity in man due to a new variant of hepatitis $B$ virus. Vaccine. 1990;8:15-17. 